\title{
Effects of Planting Dates on Green Manure of Cowpea (Vigna unguiculata l.), Response of Succeeding Maize in a Derived Savanna Ecological Zone of Nigeria
}

\author{
Thomas Oladeji Fabunmi ${ }^{1}$, Sunday Ojo Adigbo ${ }^{1}$, Joy Nwakaego Odedina ${ }^{1} \&$ Tola Omolayo Olasunkanmi ${ }^{1}$ \\ ${ }^{1}$ Department of Plant Physiology and Crop Production, University of Agriculture. P.M.B. 2240, Abeokuta, Ogun \\ State, Nigeria \\ Correspondence: Thomas Oladeji Fabunmi, Department of Plant Physiology and Crop Production, University of \\ Agriculture. P.M.B. 2240, Abeokuta, Ogun State, Nigeria. Tel: 234-803-942-3605. E-mail: tomdeji@yahoo.com
}

Received: March 2, 2012 Accepted: March 19, 2012 Online Published: May 22, 2012

doi:10.5539/jas.v4n7p57 URL: http://dx.doi.org/10.5539/jas.v4n7p57

\begin{abstract}
A study was carried out in the University of Agriculture, Abeokuta, to identify a niche for growing green manure in the derived savannah of Nigeria. Two local cowpea varieties were grown on 20th and 27th of March and 3rd of April 2009; $10^{\text {th }}, 17^{\text {th }}$ and $24^{\text {th }}$ March, 2010 in a $2 \times 3$ factorial arrangement in a randomized complete block design. Open pollinated maize was planted as a test crop a week after incorporation of the green manure. Total biomass of cowpea was low in 2009 relative to 2010. Cowpea green manuring led to grain yield increase of succeeding maize by $92-131 \%$ and $43-124 \%$ in 2009 and 2010 respectively. The erratic rains in mid March to first week in April could provide sufficient moisture for the growth of cowpea for green manure in this ecological zone and could ameliorate the effect of drought condition occasioned by climate change.
\end{abstract}

Keywords: cowpea, green manure, maize, grain yield, planting dates

\section{Introduction}

Low yield of arable crops is a common occurrence in most production systems in the humid tropics (Schroth and Sinclair 2003); identified factors associated with this include incidences of pests and diseases, weed infestations, and low inherent soil fertility (Gachene et al., 2000, Ismaila et al., 2010). The problem of low inherent soil nutrient is further aggravated by high rate of mineralization of organic matter due to high temperature and humidity; as well as torrential rainfall leading to high rate of erosion and leaching (Lal, 1983). Combined efforts directed towards ameliorating the fertility problem include use of bush fallowing, inclusion of legumes in crop rotation and as a component in cropping systems, use of inorganic fertilizers, and use of animal manure. Associated with the above ameliorative efforts include shortening of the length of bush fallow below that which could have any meaningful impact on the natural recuperation of the soil nutrient because of demographic pressure (Chikoye et al., 2002, Ismaila et al., 2010). Leguminous crops do not usually have immediate benefit on availability of nutrient to other component crops, and on the long run total contribution to soil nutrient is meagre due to high carbon content of the residue as well as crop removal. High crop yields can be obtained with judicious application of inorganic fertilizers, however the use of high chemical inputs cannot be sustained; Inorganic fertilizers are scarce and when available the price is often beyond the reach of resource poor farmer and there might be pollution risks (Okpara et al., 2003). Animal manures are bulky and transportation is often a constraint. Tarawali (1999) had shown that the use of green manure cover crops for soil fertility regeneration is among the most promising technologies to reverse the problems of land impoverishment for the rural poor. Green manuring which is defined as the soil incorporation of any field or forage crop while green or soon after flowering (Sullivan, 2003) has been reported to have tremendous benefit in crop production. When legumes are used as green manure they fix atmospheric nitrogen. Green manure can be used as alternatives to mineral fertilizers particularly for subsistence farmers whose resource base is small (Clement, 1998); incidentally $98 \%$ of total food production in Nigeria comes from subsistence agriculture (Ozowa, 1995). Use of green manure is also a means of mitigating the adverse effect of climate change and this is currently of both local and global concern. Green manuring can both serve to extend the period of soil cover as well as reduce the dependence on inorganic fertilizer. Climate-friendly agricultural practices focus on increasing the carbon content in soil (e.g. by using cover crops, ) and minimizing the need for chemical fertilizers (responsible for nitrous oxide emissions); 
and organic farming has been identified as one of the low-emission farming systems (Schaffnit-Chatterjee, 2011). Although green manure contributes immensely to soil fertility, it is seldom practised by farmers in Nigeria. One of the constraints is identifying a niche for growing the green manure without encroaching into the normal growing season as this might reduced the period available for cropping. Over the years it had been observed that some amount of rain is received before it stabilizes in the derived savannah ecological zone of Nigeria that is between January and April (Table 1). Due to the erratic, uncertain and wide intervals between successive rains in this period, the period is often used for land clearing rather than for growing of arable crops. Cowpea (Vigna unguiculata L.) is a widely grown leguminous crop in Nigeria. Cowpea has a high potential as green manure. It is adapted to a wide range of soils from sandy to heavy and it is also moderately tolerant of drought and grows well in warm seasons with $25-35^{\circ} \mathrm{C}$ as optimum temperature (Whitbread \& Lawrence, 2006). Cowpea has also been reported to have the potential of contributing as high as $80 \mathrm{~kg} \mathrm{ha}^{-1}$ of nitrogen to a subsequent crop when used as green manure (Whitbread \& Lawrence, 2006). The aim of this study is therefore to evaluate effects of planting dates on green manure potentials of two varieties of cowpea (Vigna unguiculata $L$.) in a derived savannah ecological zone of Nigeria. The objectives of this study are:

1) To identify earliest time for growing green manure without encroaching into the season for the main crop in Abeokuta, Ogun State - a derived savannah ecological zone of Nigeria.

2) To evaluate the performance of two cowpea varieties when used as green manure.

3) To evaluate the yield advantage of using cowpea green manure.

Table 1. Total rainfall and number of rainy days from January to April 2006- 2010

\begin{tabular}{lcclcccccccc}
\hline Month & \multicolumn{3}{c}{ Total monthly rainfall $(\mathrm{mm})$} & \multicolumn{4}{c}{ Number of rainy days per month } \\
\hline & 2006 & 2007 & 2008 & 2009 & 2010 & 2006 & 2007 & 2008 & 2009 & 2010 \\
\hline Jan. & 4.5 & 0.5 & 0.0 & 0.0 & 4.4 & 1 & 1 & 0 & 0 & 1 \\
Feb. & 62.0 & 0.0 & 0.0 & 59.1 & 41.2 & 5 & 0 & 0 & 5 & 3 \\
Mar. & 62.1 & 34.8 & 91.0 & 67.3 & 58.9 & 6 & 2 & 9 & 5 & 4 \\
Apr. & 180.3 & 17.2 & 128.8 & 274.0 & 112.7 & 11 & 2 & 9 & 9 & 10 \\
\hline
\end{tabular}

\section{Materials and Methods}

The experiment was carried out in the teaching research farm of the University of Agriculture, Abeokuta, Ogun Sate, Nigeria; Latitude $7^{0} 10^{1} \mathrm{~N}$ and longitude $3^{0} 26^{1}$ between March to September 2009 and March to August 2010. Composite soil sample was taken at a depth of $0-20 \mathrm{~cm}$ and bulked for routine analysis before planting and the field was prepared mechanically.

Two popular cowpea varieties in the zone (cv. Oloyin and Drum) were grown on three different dates (20th and 27th of March and 3rd of April 2009; $10^{\text {th }}, 17^{\text {th }}$ and $24^{\text {th }}$ March, 2010) in a $2 \times 3$ factorial combinations arranged in a randomized complete block design. Variety Oloyin grows erect, while drum creeps. Both cowpea varieties were planted at $50 \mathrm{~cm} \times 50 \mathrm{~cm}$ and two plants per stand, to give a population density of 80,000 plants ha ${ }^{-1}$. Seven weeks after the first planting date, the cowpea was uprooted and manually incorporated in situ across all treatments; such that for the first, second and third planting dates, the cowpea was 7, 6 and 5 weeks old, respectively at the time of incorporation. One week after incorporation open pollinated maize Suwan- 1- Y was planted in each of the six green manure plots per block and a control (no green manure) plot formed the seventh treatment. The spacing adopted for maize was $75 \mathrm{~cm} \times 50 \mathrm{~cm}$ and two plants per stand giving population density of 53,333 plants ha ${ }^{-1}$.

Data collected on cowpea were plant height and canopy width at 2 and 5 weeks after planting (WAP), dry weight at $5 \mathrm{WAP}$ and plant fresh weight from $4 \mathrm{~m}^{2}$ at time of incorporation. Parameters taken on maize were plant height and canopy width from 2 WAP(weeks after planting) fortnightly till $10 \mathrm{WAP}$; while leaf chlorophyll content was taken from the newest, fully expanded leaf (as recommended in the manual), using the Minolta chlorophyll meter ( model SPAD 502) at 3, 6 and 9 WAP only in 2010. Others data collected on maize include number of days to $50 \%$ teaselling, grain yield, cob length, and cob girth. Data collected were subjected to Analysis of Variance (ANOVA) and significant means were separated using Least Significant Difference (LSD) at 5\% level of probability. Two sets of analysis were carried out, the first analysis was done based on the factors in the experimental design; the second was carried out to evaluate the performance of succeeding maize with or without the green manure. 


\section{Results}

\subsection{Chemical Properties of Soil of the Experimental Site before Planting}

Soil sample was collected from the experimental site before planting and the results of the chemical properties are presented in Table 2 .

Table 2. Chemical properties of soil of the experimental site before planting

\begin{tabular}{ll}
\hline Soil characteristics & Composition \\
\hline Soil $\mathrm{pH}$ & 6.5 \\
Available phosphorus & $16.1 \mathrm{ppm}$ \\
Organic carbon & $1.4 \%$ \\
Total Nitrogen & $0.15 \%$ \\
Exchangeable carbon & $1.89 \mathrm{meq} / 100 \mathrm{~g}$ \\
Exchangeable potassium & $0.40 \mathrm{meq} / 100 \mathrm{~g}$ \\
Exchangeable magnesium & $0.66 \mathrm{meq} / 100 \mathrm{~g}$ \\
Soil colour & Dark brown \\
\hline
\end{tabular}

The $\mathrm{pH}$ of the soil is near neutral, available phosphorus is medium, organic carbon is moderate, total nitrogen is moderately low, exchangeable calcium is very low, exchangeable potassium is medium and exchangeable magnesium is low.

\subsection{Effect of Planting Dates and Varieties on Growth, Plant Biomass and Dry Weight of Cowpea}

Canopy height of cowpea was not significantly affected by dates of planting and cowpea varieties in 2009; on the other hand in 2010, canopy height was significantly affected by planting date both at 2 and 5 WAP. While first and second planting dates gave higher $(\mathrm{p}<0.05)$ canopy height at $2 \mathrm{WAP}$, significantly higher value was obtained from the third planting date in 2010 (Table 3). Plant biomass at incorporation was not significantly different across the planting dates and varieties in 2009. In 2010 however, similar ( $p>0.05)$ biomass were produced in both first and second planting date which were significantly higher than the third planting date. The total biomass obtained across the two varieties and the planting dates were generally low in 2009 as compared to the values obtained in 2010 . The third planting date gave the highest $(\mathrm{p}<0.05)$ dry weight per plant at 5 WAP in 2010, a similar result was obtained in 2009 even though there was no significant difference ( $>>0.05$ ) (Table 3 ). The result also showed no significant interaction between the planting dates and varieties in all measured parameters (Table 3).

Table 3. Effect of planting dates and varieties on canopy height, plant biomass, dry matter of cowpea used as green manure

\begin{tabular}{|c|c|c|c|c|c|c|c|c|c|c|}
\hline \multirow[t]{2}{*}{ Treatment } & \multicolumn{3}{|c|}{ height $(\mathrm{cm})$ at WAP } & Canopy & \multicolumn{2}{|c|}{$\begin{array}{l}\text { Plant biomass at } \\
\text { incorporation }(\mathrm{t} / \mathrm{ha})\end{array}$} & \multicolumn{2}{|c|}{$\begin{array}{l}\text { Dry matter(t/ha) } \\
\text { At WAP }\end{array}$} & \multicolumn{2}{|c|}{$\begin{array}{l}\text { Dry weight } \\
\text { (g/plant) } \\
\text { at } \\
\text { WAP }\end{array}$} \\
\hline & & 2009 & & 2010 & 2009 & 2010 & 2009 & 2010 & 2009 & 2010 \\
\hline Planting date & 2 & 5 & 2 & 5 & & & 5 & 5 & 5 & 5 \\
\hline March 10(20) & 12.5 & 25.1 & 20.6 & 33.3 & 5.4 & 16.1 & 0.1135 & 0.1917 & 18.7 & 15.4 \\
\hline March 17(27) & 11.4 & 24.7 & 21.0 & 34.9 & 6.1 & 19.6 & 0.1318 & 0.1233 & 20.6 & 14.3 \\
\hline $\begin{array}{l}\text { March 24(April } \\
\text { 3) }\end{array}$ & 11.4 & 27.7 & 15.9 & 45.3 & 6.9 & 5.29 & 0.1033 & 0.1400 & 27.1 & 25.5 \\
\hline $\begin{array}{l}\text { LSD } \\
\text { Variety }\end{array}$ & NS & NS & 2.72 & 5.08 & NS & 4.963 & NS & 0.0493 & NS & 4.54 \\
\hline Drum & 11.5 & 24.1 & 19.0 & 35.8 & 5.6 & 12.50 & 0.1162 & 0.1533 & 20.4 & 16.9 \\
\hline Oloyin & 12.0 & 27.5 & 19.3 & 39.9 & 6.7 & 14.86 & 0.1162 & 0.1500 & 23.9 & 19.9 \\
\hline $\begin{array}{l}\text { LSD } \\
\text { Treatment } \\
\text { Interaction }\end{array}$ & 1.18 & 5.12 & NS & NS & NS & NS & NS & NS & NS & NS \\
\hline LSD & NS & NS & NS & NS & NS & NS & NS & NS & & NS \\
\hline
\end{tabular}

NS: Not significant WAP: weeks after planting (April 3): Planting date in 2010 
Although there was no significant difference in all the parameter taken between the two varieties of cowpea, variety Oloyin had higher values ( $\mathrm{p}>0.05$ ) across all parameters and in both years.

\subsection{Growth Response of Succeeding Maize to Planting Dates and Varieties of Preceding Cowpea Green Manure}

Plant height of succeeding maize responded significantly to date of planting of preceding cowpea green manure at 8 WAP in 2010 only. Maize planted on plots where green manure was planted first had taller $(\mathrm{p}<0.05)$ plants compared to where green manure was planted 2 weeks later (planting date 3 ). There was no significant difference in plant height of maize grown on green manure plots planted on first and second planting date (Table 4).

Table 4. Effect of date of planting and variety of preceding cowpea green manure on the response of plant height of maize

\begin{tabular}{|c|c|c|c|c|c|c|c|c|c|c|}
\hline \multirow[t]{2}{*}{ Treatment } & & & & & \multicolumn{6}{|c|}{ Plant height at different weeks after planting $(\mathrm{cm})$} \\
\hline & 2009 & & & & & 2010 & & & & \\
\hline Planting date & 2 & 4 & 6 & 8 & 10 & 2 & 4 & 6 & 8 & 10 \\
\hline March 10(20) & 11.7 & 55.5 & 122.7 & 176.8 & 181.9 & 15.3 & 45.1 & 115.1 & 158.1 & 164.4 \\
\hline March 17(27) & 10.8 & 49.5 & 107.9 & 168.8 & 171.7 & 14.6 & 52.0 & 108.0 & 152.2 & 155.5 \\
\hline March 24(April 3) & 9.9 & 52.0 & 111.8 & 163.5 & 171.4 & 14.2 & 46.4 & 97.3 & 131.9 & 140.3 \\
\hline LSD & NS & NS & NS & NS & NS & NS & NS & NS & 21.2 & NS \\
\hline \multicolumn{11}{|l|}{ Variety } \\
\hline Drum & 10.0 & 50.3 & 101.9 & 157.3 & 162.3 & 14.6 & 48.1 & 108.6 & 144.3 & 149.0 \\
\hline Oloyin & 11.6 & 54.4 & 126.3 & 182.1 & 187.7 & 14.9 & 47.5 & 104.9 & 150.6 & 157.8 \\
\hline LSD & NS & NS & 11.86 & 9.41 & 13.10 & NS & NS & NS & NS & NS \\
\hline \multicolumn{11}{|l|}{ Treatment } \\
\hline Interaction & & & & & & & & & & \\
\hline LSD & NS & NS & NS & NS & NS & NS & NS & NS & NS & NS \\
\hline
\end{tabular}

Green manure from cowpea variety Oloyin consistently gave significantly taller plant $(\mathrm{p}<0.05)$ at 6,8 and 10 WAP in 2009. In 2010 maize on Oloyin plots were also taller ( $>0.05)$ at 8 and 10 WAP than those on Drum plots.

Similarly canopy spread of maize were wider $(\mathrm{p}<0.05)$ on plots where cowpea green manure was planted first and a week later at 6 and 10 WAP relative to maize canopy spread on green manure planted on the third planting date (Table5). Although a consistent trend was observed across all the period of measurement, varietal effect of preceding cowpea green manure was significant only at 4WAP of maize in 2009, where maize on preceding plot of Oloyin performed better than Drum. No significant varietal effect was obtained in 2010.

Table 5. Effect of date of planting and variety of preceding cowpea green manure on the response of canopy width of maize

\begin{tabular}{|c|c|c|c|c|c|c|c|c|c|c|}
\hline \multirow[t]{2}{*}{ Treatment } & \multicolumn{10}{|c|}{ Canopy width at different weeks after planting $(\mathrm{cm})$} \\
\hline & 2009 & & & & & 2010 & & & & \\
\hline Planting date & 2 & 4 & 6 & 8 & 10 & 2 & 4 & 6 & 8 & 10 \\
\hline March 10(20) & 24.6 & 64.2 & 72.0 & 84.1 & 65.8 & 20.2 & 60.4 & 93.6 & 99.5 & 103.6 \\
\hline March 17(27) & 24.1 & 58.8 & 64.9 & 80.5 & 65.5 & 20.2 & 60.5 & 92.0 & 99.2 & 100.8 \\
\hline March 24(April 3) & 24.1 & 60.6 & 64.5 & 81.3 & 68.5 & 20.0 & 54.2 & 82.4 & 91.7 & 94.0 \\
\hline LSD & NS & NS & NS & NS & NS & NS & NS & 5.71 & NS & 7.03 \\
\hline \multicolumn{11}{|l|}{ Variety } \\
\hline Drum & 23.8 & 53.0 & 64.6 & 79.6 & 63.6 & 20.8 & 57.5 & 87.6 & 96.9 & 99.2 \\
\hline Oloyin & 24.8 & 69.4 & 69.8 & 84.4 & 69.6 & 19.5 & 59.3 & 91.1 & 96.8 & 94.0 \\
\hline LSD & NS & 11.65 & NS & NS & NS & NS & NS & NS & NS & NS \\
\hline \multicolumn{11}{|l|}{$\begin{array}{l}\text { Treatment } \\
\text { Interaction }\end{array}$} \\
\hline LSD & NS & NS & NS & NS & NS & NS & NS & NS & NS & NS \\
\hline
\end{tabular}

NS: Not significant

(April 3): Planting date in 2010 


\subsection{Leaf Chlorophyll Response of Succeeding Maize to Planting Dates and Varieties of Preceding Cowpea Green Manure}

Leaf chlorophyll content of maize measured at 6 weeks after planting responded significantly to the planting date of preceding green manure $(p<0.05)$; the chlorophyll content of maize on plots where cowpea was planted first and seven days later were similar at 6 WAP $(p>0.05)$ and significantly different from those on plots where the green manure was planted two weeks after the first planting ( $3^{\text {rd }}$ planting date). Leaf chlorophyll content of succeeding maize showed no significant response to varieties of preceding cowpea used as green manure. Leaf chlorophyll content increased generally from 3 to 6 WAP and then declined at 9 WAP across the planting dates and varieties (Table 6).

Table 6. Effect of date of planting and variety of preceding cowpea green manure on the chlorophyll content of succeeding maize at different weeks after planting (WAP) in 2010

\begin{tabular}{llll}
\hline Treatment & 3WAP & 6WAP & 9WAP \\
\hline Planting date & & & \\
\hline March 10(20) & 32.4 & 37.8 & 34.2 \\
March 17(27) & 35.2 & 39.4 & 36.4 \\
March 24(April 3) & 31.2 & 31.1 & 29.8 \\
LSD & NS & $\mathbf{3 . 8 8}$ & NS \\
Variety & & & \\
Drum & 32.9 & 35.9 & 32.2 \\
Oloyin & 32.9 & 36.3 & 34.8 \\
LSD & NS & NS & NS \\
Treatment Interaction & & & \\
LSD & NS & NS & NS \\
\hline
\end{tabular}

NS: Not significant

WAP: weeks after planting (April 3): Planting date in 2010

\subsection{Effect of Date of Planting and Variety of Preceding Cowpea Used as Green Manure on Yield and Yield Components of Maize}

Generally, maize grain yield and yield components were not significantly affected by both the dates of planting and varieties of cowpea used in this study (Table 7). Maize grain yield from cowpea green manure plots of first planting date was however higher $(\mathrm{p}>0.05$ ) in both years relative to those from 2 nd and third planting dates of green manure. Similarly, the varieties of cowpea used as green manure had no significant effect on the grain yield and yield components of the succeeding maize; however grain yield of maize on Oloyin plot was higher $(p>0.05)$ in both years. The cob girth of maize showed significant response to planting date of cowpea in 2010.

Table 7. Effect of date of planting and variety of preceding cowpea green manure on the response of Grain yield and yield components of maize

\begin{tabular}{lllllllll}
\hline Treatment & \multicolumn{2}{l}{$\begin{array}{l}\text { Grain yield } \\
(\mathrm{t} / \mathrm{ha})\end{array}$} & \multicolumn{2}{l}{ 100 grain weight $(\mathrm{g})$} & Cob girth $(\mathrm{cm})$ & Cob length(cm) \\
\hline & 2009 & 2010 & 2009 & 2010 & 2009 & 2010 & 2009 & 2010 \\
\hline Planting date & & & & & & & & \\
March 10(20) & 1.76 & 2.48 & 22.0 & 16.5 & 13.8 & 14.4 & 11.5 & 9.6 \\
March 17(27) & 1.60 & 2.17 & 21.0 & 17.5 & 13.7 & 13.0 & 11.1 & 10.6 \\
March 24(April 3) & 1.73 & 1.94 & 21.8 & 15.5 & 13.9 & 13.2 & 11.1 & 10.0 \\
LSD & NS & NS & NS & NS & NS & $\mathbf{1 . 0 6}$ & NS & NS \\
Variety & & & & & & & & \\
Drum & 1.63 & 2.08 & 21.3 & 16.5 & 13.6 & 13.8 & 11.1 & 9.4 \\
Oloyin & 1.76 & 2.32 & 21.9 & 16.2 & 14.0 & 13.3 & 11.4 & 10.7 \\
;LSD & NS & NS & NS & NS & NS & NS & NS & NS \\
Treatment Interaction & & & & & & & & \\
LSD & NS & NS & NS & NS & NS & NS & NS & NS \\
\hline
\end{tabular}

NS: Not significant

(April 3): Planting date in 2010 
Table 8. Plant height of succeeding maize as influenced by cowpea green manure

\begin{tabular}{lrlllrlllll}
\hline Treatment & \multicolumn{1}{c}{ 2 } & \multicolumn{1}{c}{ Plant height $(\mathrm{cm})$} \\
\hline & 2009 & 2010 & 2009 & 2010 & \multicolumn{2}{c}{ 6WAP } & \multicolumn{1}{c}{ 8WAP } & \multicolumn{1}{c}{ 10WAP } \\
\hline Drum March 10(20) & 11.0 & 14.0 & 55.1 & 49.4 & 109.5 & 125.0 & 160.9 & 165.3 & 167.9 & 168.5 \\
Drum March 17(27) & 10.3 & 14.5 & 44.5 & 47.5 & 88.7 & 100.8 & 152.3 & 139.7 & 156.4 & 142.5 \\
Drum March 24(April 3) & 8.7 & 14.7 & 51.3 & 47.5 & 107.5 & 100.1 & 158.7 & 127.7 & 162.5 & 136.1 \\
Oloyin March 10(20) & 12.5 & 16.1 & 55.9 & 40.9 & 135.9 & 105.1 & 192.8 & 151.0 & 195.8 & 160.4 \\
Oloyin March 17(27) & 11.3 & 14.7 & 54.5 & 56.5 & 127.0 & 115.1 & 185.3 & 164.6 & 187.0 & 168.4 \\
Oloyin March 24(April 3) & 11.0 & 13.8 & 52.6 & 45.2 & 116.0 & 94.5 & 168.2 & 136.1 & 180.3 & 144.6 \\
Sole maize & 5.7 & 12.2 & 39.1 & 36.1 & 71.7 & 78.5 & 113.0 & 126.1 & 139.4 & 128.8 \\
LSD & $\mathbf{3 . 9 2}$ & NS & NS & NS & $\mathbf{1 9 . 4 2}$ & $\mathbf{2 2 . 3 0}$ & $\mathbf{2 4 . 8 3}$ & $\mathbf{2 7 . 8 2}$ & $\mathbf{2 3 . 0 1}$ & $\mathbf{2 7 . 7 3}$ \\
\hline
\end{tabular}

NS: Not significant WAP: weeks after planting (April 3): Planting date in 2010

\subsection{Effect of Preceding Green Manure Application on Growth of Maize}

Plant height of maize was significantly enhanced by preceding green manure (Table 8). In 2009, maize on all green manure plots irrespective of the varieties of cowpea planted and the planting dates, grew taller $(\mathrm{p}<0.05)$ relative to the control plots at 2,6,8 and 10 WAP. Exceptions to this were plant height of maize on pd3 Drum and pd2 Drum which were not significantly different from the control at 2WAP, and 6 and 10 WAP respectively. On the green manure treated plots, maize on pd1 Oloyin produced significantly taller plants than all other treatments at 6, 8 and 10 WAP. In 2010, response to green manure application was observed at 6,8 and 10 WAP. However at 6 WAP all green manure treated plots but pd 3 of both cowpea varieties had significantly taller plants than the control. Generally the most significant response was obtained from green manure of both cowpea varieties at pd1 and $\mathrm{pd} 2$. In both years the plant height taken at $10 \mathrm{WAP}$ when all maize had tassel revealed that maize on all green manure plots in 2009 apart from those on drum pd2 were significantly taller than those on the control plots. In 2010 0n the other hand, although maize on all the green manure treated plots grew taller than those on the control plots, only those on green manure plots planted on the $\mathrm{pd} 1$ in both varieties were significantly taller.

Canopy spread of maize also showed some significant responses to green manure application (Table 9). In 2009, all green manure treated plot had wider $(\mathrm{p}<0.05)$ canopy at 2 and 4 WAP, the only exception was maize plant grown on pd3 of Drum which was not significantly different from the control. In 2010 canopy spread of maize increased significantly $(\mathrm{p}<0.05)$ on green manure plots of $\mathrm{pd} 1$ and $\mathrm{pd} 2$ of both cowpea varieties only at 4 WAP while at 6 WAP significant response to green manure application was observed only on pd1 and $\mathrm{pd} 2$ of Oloyin, and pd1 of Drum.

Table 9. Canopy width of succeeding maize as influenced by date of planting and varieties of cowpea green manure

\begin{tabular}{lcccccccccc}
\hline Treatment & \multicolumn{10}{c}{ Canopy width (cm) } \\
\hline & \multicolumn{1}{c}{ 2WAP } & & 4WAP & & 6WAP & 8WAP & 10WAP \\
\hline & 2009 & 2010 & 2009 & 2010 & 2009 & 2010 & 2009 & 2010 & 2009 & 2010 \\
Drum March 10(20) & 25.1 & 20.3 & 54.3 & 61.3 & 67.9 & 93.8 & 81.7 & 102.0 & 63.9 & 103.9 \\
Drum March 17(27) & 24.7 & 20.9 & 51.7 & 56.7 & 58.1 & 88.5 & 76.6 & 96.7 & 63.3 & 98.7 \\
Drum March 24(April 3) & 21.6 & 21.2 & 52.9 & 54.1 & 67.7 & 80.6 & 80.5 & 92.0 & 63.5 & 95.0 \\
Oloyin March 10(20) & 24.1 & 20.2 & 74.0 & 59.9 & 76.2 & 93.4 & 86.6 & 97.0 & 67.7 & 103.3 \\
Oloyin March 17(27) & 23.5 & 19.5 & 65.9 & 64.0 & 71.7 & 95.5 & 84.4 & 101.7 & 67.7 & 102.9 \\
Oloyin March 24(April 3) & 26.6 & 18.8 & 68.3 & 54.3 & 61.4 & 84.3 & 82.1 & 91.5 & 73.5 & 93.0 \\
Sole maize & 19.3 & 18.5 & 41.7 & 45.6 & 47.8 & 79.1 & 68.7 & 88.0 & 53.0 & 89.8 \\
LSD & $\mathbf{3 . 5 1}$ & NS & $\mathbf{8 . 6 5}$ & $\mathbf{1 0 . 1 9}$ & NS & $\mathbf{1 0 . 9 5}$ & NS & NS & NS & NS \\
\hline
\end{tabular}

NS: Not significant WAP: weeks after planting (April 3): Planting date in 2010

\subsection{Response of Chlorophyll Content in Maize Leaf to Green Manure Application}

Green manure application significantly affected the leaf chlorophyll content of maize at 3 and 6 WAP $(\mathrm{p}<0.05)$. Maize leaf canopy increased significantly on plots pd1 and $\mathrm{pd} 2$ of both cowpea varieties Leaf chlorophyll content increased from 3 to $6 \mathrm{WAP}$ and then declined at $9 \mathrm{WAP}$ across all treatment and control plots (Figure 1). 


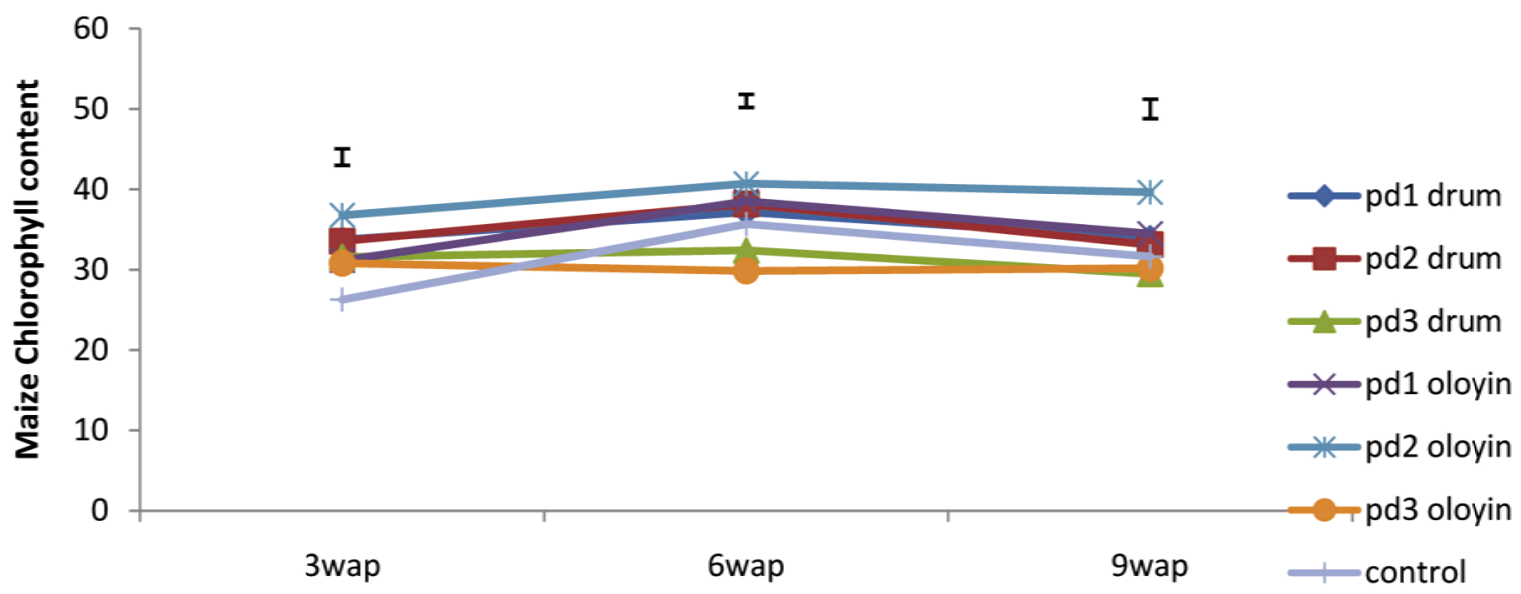

Figure 1. Leaf chlorophyll content of succeeding maize( at 3,6,and 9 weeks after planting) on different preceding cowpea green manure plots planted on different dates ( $\mathrm{pd} 1, \mathrm{pd} 2$ and $\mathrm{pd} 3$ ) and control in 2010

\subsection{Maize Grain Yield and yield Components Response to Green Manure Application}

Maize grain yield was significantly influenced $(\mathrm{p}<0.05)$ by green manure application in this trial (Table 10$)$. In 2009 , maize grain yield from all green manure treated plots ranked same but higher $(p<0.05)$ than the control. In 2010 however, maize on all preceding green manure plots of Oloyin ( $\mathrm{pd} 1, \mathrm{pd} 2$ and $\mathrm{pd} 3$ ) and drum $\mathrm{pd} 1$ and $\mathrm{pd} 3$ produced maize grain yield significantly higher than the control plot; while the only drum treatment with maize yield not significantly higher than the control was pd2. Generally there was $92-131 \%$ and $43-124 \%$ grain yield increase of maize in 2009 and 2010 respectively in the green manure plots relative to the grain yield from the control plots.

Table 10. Grain yield and yield components of succeeding maize as influenced by date of planting and varieties of cowpea used as green manure

\begin{tabular}{|c|c|c|c|c|c|c|c|c|}
\hline Treatment & $\begin{array}{l}\text { Grain } \\
(\mathrm{t} / \mathrm{ha})\end{array}$ & yield & $\begin{array}{l}\% \text { ir } \\
\text { sole } \mathrm{r}\end{array}$ & se over & Cob le & $(\mathrm{cm})$ & Cob gi & m) \\
\hline $\begin{array}{l}\text { Planting date of cowpea } \\
\text { variety used as green } \\
\text { manure }\end{array}$ & 2009 & 2010 & 2009 & 2010 & $\begin{array}{l}2009 \\
2010\end{array}$ & & $\begin{array}{l}2009 \\
2010\end{array}$ & \\
\hline Drum March 10(20) & 1.88 & 2.67 & 131 & 124 & 11.30 & 9.23 & 13.80 & 15.57 \\
\hline Drum March 17(27) & 1.63 & 1.87 & 100 & 57 & 11.53 & 9.83 & 14.10 & 12.65 \\
\hline Drum March 24(April 3) & 1.77 & 1.70 & 118 & 43 & 11.37 & 9.18 & 14.13. & 13.12 \\
\hline Oloyin March 10(20) & 1.63 & 2.29 & 100 & 92 & 11.73 & 9.97 & 13.83 & 13.23 \\
\hline Oloyin March 17(27) & 1.56 & 2.48 & 92 & 108 & 10.67 & 11.30 & 13.37 & 13.43 \\
\hline Oloyin March 24(April 3) & 1.68 & 2.18 & 107 & 83 & 10.80 & 10.88 & 13.67 & 13.33 \\
\hline Sole maize & 0.813 & 1.19 & & & 8.90 & 7.83 & 10.77 & 11.67 \\
\hline LSD & 0.568 & 0.847 & & & NS & NS & NS & 1.365 \\
\hline
\end{tabular}

NS: Not significant

(April 3): Planting date in 2010

Maize cob length and cob girth from all the green manure plots were generally higher $(p>0.05)$ than the control plot in both years; however significant difference between cob girth was observed only in 2010 (Table 10).

\section{Discussions}

In this study, although the canopy height of cowpea was not significantly different between treatments in 2009, the relatively higher value obtained in the third planting date suggests that the growth condition in the first and second planting dates would have been sub-optimal. This can be confirmed by the significant difference observed in the canopy height between different treatments in 2010 where the third planting date produced plants with tallest canopy.

The fact that similar biomass was available for incorporation in 2009 also support the earlier deduction above, that the growth condition for the first and second planting date would have been sub optimal. This is because in spite of the fact that plants harvested for incorporation were only five weeks old for the third planting date, the biomass produced was still higher than those obtained from plants grown fourteen or seven days earlier, that is 
the first and second planting dates respectively. This was further affirmed by the result obtained in 2010 as the biomass obtained from the third planting date was the least compared to the first and second planting dates. The implication is that in 2010 more enabling growth condition must have been available for the first and second planting; thus at the time of harvest, the advantage of planting one or two weeks earlier led to production of higher biomass in the first and second planting date. Hence, the variations observed in the biomass production in 2010 can be attributed to different ages of plants at the time of incorporation. In 2010 even though the plant biomass produced on the third planting date was low, it is comparable to the biomass obtained for the first and second planting dates in 2009. Relatively higher biomass production by the cowpea variety Oloyin compared to Drum could be because Oloyin matures early than Drum, thus when used as green manures it reaches its peak biomass accumulation faster. The fact that similar biomass were harvested irrespective of the planting dates in 2009, while high variability was observed in 2010 can be attributed to the erratic pattern of rains associated with the early part of the rainy season. Soil moisture stress has been reported to have significantly reduced the growth of three cowpea cultivars in Nigeria (Babalola, 1980). Delayed planting date, poor stand establishment and drought have been identified as factors that limit growth of legumes (Sullivan, 2003) .

The significant increase obtained in dry weight of plants on the third planting date at 5 WAP compared with the dry weight of plants of same age from the first and second planting dates, suggests that a more favourable conditions for dry matter accumulation was obtained at the third planting. The more likely improved condition was more moisture availability as the rains become more stable. This however did not translate into higher biomass production in 2010; this was because plants established earlier had the advantage of additional time to grow (7-14 days) before they were uprooted for incorporation.

The successful planting of maize one week after incorporation of the green manure in contrast to two weeks suggested in literatures, could be attributed to the prevalent of relatively high temperature in the tropics.

The significant response of maize plant height at 8 WAP to date of planting of cowpea green manure in 2010 could be attributed to higher dry matter accumulation of the green manure incorporated; the decomposition of more biomass would have led to the release of more nutrient and better growth of maize, especially for the first and second planting of green manure. Taller maize plant from Oloyin plot could be attributed to the maturity date of the cowpea as it matures earlier than Drum and as such attains maximum biomass accumulation earlier than Drum.

The significant response of leaf chlorophyll of succeeding maize to planting date of green manure can also be attributed to the fact that early planting of green manure led to the production of more biomass hence release of more nutrient from the incorporation of such when compared with those planted 2 weeks later. Furthermore, more atmospheric nitrogen would have been fixed by cowpea planted earlier relative to those planted one or two weeks later; thus making more nitrogen to be available for the uptake of the succeeding crop leading to production of leaves with higher chlorophyll content. The amount of nitrogen available from legumes depends amongst other factors, on the amount of the total biomass produced (Sullivan, 2003).

In the present study, although grain yield and almost all yield components of maize showed no significant response to either date of planting or variety of preceding cowpea used as green manure, the general trend observed in which grain yield of succeeding maize was more with early planting of green manure suggest that early planting of the green manure crop is more advantageous than later planting and that the more moisture availability as one advances into the rainy season could not compensate for the lost of time when planted a week or two weeks later. This also suggests that the green manure crop (cowpea) can be planted as from the $10^{\text {th }}$ or $20^{\text {th }}$ of March as done in 2009 and 2010 respectively in this study.

The growth response of maize grown on green manure plots relative to those on control plots in this trial could be attributed to increased organic matter, nitrogen and possibly other nutrient released from the incorporated green manure. Whitbread and Lawrence (2006) reported that cowpea green manure has the potential of contributing up to $80 \mathrm{Kg} \mathrm{N}^{-1}{ }^{-1}$ to subsequent crop. The variations observed between plant heights and canopy widths of maize in both years could be attributed to both variations in the amount of green manure biomass incorporated as well as the varieties of cowpea producing the green manure. The relatively better growth of maize on plots of variety Oloyin could be attributed relatively higher biomass produced by the cowpea variety in both years. On the other hand, taller plants and wider canopy of plants grown on $\mathrm{pd} 1$ and $\mathrm{pd} 2$ of Oloyin and $\mathrm{pd} 1$ of drum as compared to other treatments and the control (without green manure) could be attributed to more biomass that were produced and incorporated in the former due to earlier planting. This is because the amount of nitrogen available from legumes depends amongst other factors, on the amount of the total biomass produced (Sullivan, 2003). 
The significant increase in grain yield of maize in all the green manure plots relative to the control plots in this study could be attributed to improved soil conditions in terms of increased soil organic matter, soil nitrogen and other nutrients due to the addition of green manure. The increase in soil nutrient resulted in the better growth observed, thus higher dry matter was accumulated during the vegetative stage which was later partitioned into the cob during the reproductive stage. The better growth condition led to increased cob length, cob girth and ultimately grain yield of maize in the green manure plots relative to control plots in both years. Maize grain yields associated with the use of cowpea green manure were reported to have been doubled compared to the unfertilized control treatments (Whitbread \& Lawrence, 2006).Similarly, Gachene et al. (2000) reported that maize grain yield from certain green manure plots were more than doubled the yield from the unfertilized control treatments.

The results of the present study also agrees with the report of Oyango et al. (2001) that there is a great potential in using green manure legumes to sustain maize yields for resource-poor farmers.

\section{Conclusions}

In this study planting of cowpea as early as $10^{\text {th }}$ of March in 2009 and $20^{\text {th }}$ of March 2010 produced sufficient biomass of cowpea that was incorporated as green manure. Planting of maize one week after incorporation of the green manure was found to be adequate under the present climate (with high moisture and temperature) as compared with two weeks suggested in literatures. Incorporation of cowpea green manure led to a grain yield increase of succeeding maize by $92-131 \%$ and $43-124 \%$ in 2009 and 2010 respectively. It can be concluded that the erratic rains that characterize the beginnings of the season could provide sufficient moisture for the growth of cowpea green manure. This can be incorporated at the time of land preparations for arable crops. Thus this period( as early as $10^{\text {th }}-20^{\text {th }}$ March) can serve as a niche for growing green manure and enhancing the fertility of the soil, without encroaching into or shortening the regular period available for arable crop production. These findings will be of immense benefit to the resource poor farmers who are the major producer of food crops in the derived savannah ecological zone of Nigeria and areas with similar climate world over. It can also be concluded that growing of cowpea as green manure will extent the period of soil cover in a drought condition and ameliorate the negative impact of climate change.

\section{References}

Babalola, O. (1980). Water relation of three cowpea cultivars (Vigna unguiculata, L). Plant and Soil, 56, 59-69. http://dx.doi.org/10.1007/BF02197953

Chikoye, D., Manyong, V. M., Carsky, R. J., Ekeleme, F., Gbehounou, G., \& Ahanchede, A. (2002). Response of speargrass (Imperata cylindrica) to cover crops integrated with hand weeding and chemical control in maize and cassava. Crop Protection, 21, 145-156. http://dx.doi.org/10.1016/S0261-2194(01)00078-3

Clement, A., Jagdish, K., Ladha, K., \& Chalifour, F. P. (1998). Nitrogen dynamics of green manures species and relationships to lowland rice production. Agronomy Journal, 90, 149-154. http://dx.doi.org/10.2134/agronj1998.00021962009000020005x

Gachene, C. K. K., Mureithi, J. G., Anyika, F., \& Makau, M. (2000). Incorporating green manure cover crops in maize based cropping system in semiarid and sub-humid environments of Kenya. In Mureithi JG, Gachene CKK, Muyekho FN, Onyango M, Mose L, and Magenya O (eds) Participatory technology Development for Soil Management by Smallholders in Kenya. Proceedings of the 2nd Scientific Conference of the Soil Management and Legume Research network projects. June 2000, Mombasa, Kenya, pp. 145-151.

Ismaila, U., Gana, A. S., Tswanya, N. M., \& Dogara, D. (2010). Cereals production in Nigeria: Problems, constraints and opportunities for betterment. African Journal of Agricultural Research, 5(12), 1341-1350.

Lal, R. (1983). Soil erosion in the humid tropics with particular reference to agricultural land development and soil management in Hydrology of humid tropical regions with particular reference to the hydrological effects of agriculture and forestry practice (Proceedings of the Hamburg Symposium, August 1983). IAHS'Publ. No. 140.

Okpara, D. A., Ikeorgu, J. E. G., \& Njoku, J. C. (2003). Potential of cover crops for sustainable short fallow replacement in low-input systems of maize production in the humid tropics. African Crop Science Conference Proceedings, 6, 76-80.

Oyango, R. M. A., Mwangi, T. K., N'geny, J. M., Lunzalu, E., \& Barkutwo, K. (2001). Effect of relaying green manure legumes on yields of intercropped maize in smallholder farms of trans Nzola district, Kenya. Seventh Eastern and South Africa Regional maize Conference $11^{\text {th }}-15^{\text {th }}$ February, pp. 330-334. 
Ozowa, V. N. (1995). Information needs of small scale farmers in Africa: The Nigerian example. Quarterly Bulletin of the International association of agricultural information specialist, IAALD/CABI, 40, 1.

Schaffnit-Chatterjee, C. (2011). Mitigating climate change through agriculture: An untapped potential. Deutsche Bank Research September.

Schroth, G., \& Sinclair, F. L. (2003). Chapter 1: Impacts of trees on the fertility of agricultural soils. In: Schroth G. and Sinclair F.L. (eds). Trees, Crops and Soil Fertility. Concepts and Research Methods.CAB International 2003. pp. 1-13.

Sullivan, P. (2003). Overview of cover crops and green manures: Fundamentals of sustainable Agriculture. ATTRA publications, p.16.

Tarawali, S. A. (1999). An approach for the evaluation of herbaceous legumes with multiple benefits. In: Cover crops for Natural Resource Management in West Africa. Proceedings of Workshop organized by IITA CIEPCA at Cotonou, Benin, 26-29, Oct.

Whitbread, A., \& Lawrence, J. (2006). Cowpea fact sheet for Grain and Graze. CSIRO Sustainable Ecosystems, 4. 